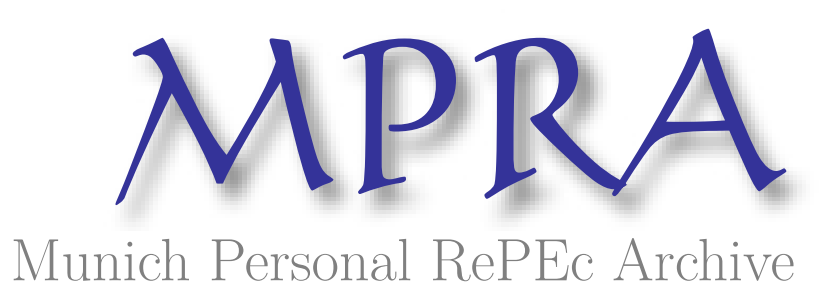

\title{
Mechanics of Global Value Chains: India's Perspective
}

Dutta, Sourish

2017

Online at https://mpra.ub.uni-muenchen.de/108482/

MPRA Paper No. 108482, posted 30 Jun 2021 06:43 UTC 
Mechanics of Global Value Chains: India's Perspective

\author{
Sourish Dutta
}

PhD Student

Centre for Development Studies

Trivandrum, Kerala 


\section{Contents}

I Research Background $\quad 4$

1 Motivation $\quad 5$

$\begin{array}{llr}2 & \text { Geographical Background } & 8\end{array}$

2.1 Global Background $\ldots \ldots \ldots \ldots \ldots \ldots \ldots \ldots$

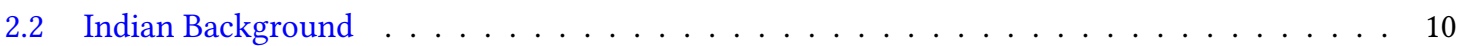

II Research Significance $\quad 12$

3 Review of the Literature $r$

3.1 Broad Perspective . . . . . . . . . . . . . . . . . . . . 13

3.2 Firm Perspective . . . . . . . . . . . . . . . . . . . . . 14

3.3 Policy Perspective . . . . . . . . . . . . . . . . . . . . . . . . . 15

3.4 Innovation Perspective $\ldots \ldots \ldots \ldots \ldots \ldots \ldots \ldots \ldots$

4 Rationale and Scope of the Study $r$

4.1 Specific Aims . . . . . . . . . . . . . . . . . . . . 20

III Research Design $\quad 21$

5 Analytical Framework of Assessing India's Potential in GVCs 22

5.1 Functions in GVCs: Buyer's and Seller's Perspectives . . . . . . . . . . . . . . . . . . . 22 
$5.2 \quad$ Specialisation and Value Addition $\ldots \ldots \ldots \ldots \ldots \ldots \ldots \ldots$

5.3 Position in GVC Networks and Type of GVC Node . . . . . . . . . . . . . . . . . . 25

5.4 Policy Implications: Entering, Expanding, and Sustaining $\ldots \ldots \ldots \ldots \ldots \ldots$

$\begin{array}{ll}\text { IV Research Methods } & 28\end{array}$

6 Quantification of GVC Links 29

6.1 GVC Participation Using Gross Trade Data . . . . . . . . . . . . . . . . . . . . . . . 29

6.2 Buyer's Perspective: Methods of Backward Links _ . . . . . . . . . . . . . . . 30

6.3 Seller's Perspective: Methods of Forward Links . . . . . . . . . . . . . . . . . . . . 31

6.4 GVC Participation: Methods from Macro to Micro . . . . . . . . . . . . . . . . . 32

7 Drivers and Impacts of GVCs $\quad 34$

7.1 Determinants of GVC Links . . . . . . . . . . . . . . . . . . . . 34

7.1.1 Decomposition of Gross Export Growth . . . . . . . . . . . . . . . . 34

7.1.2 Correlations of GVC Integration with Country-Level Characteristics . . . . . . . . 35

7.1.3 Determinants of Firm-Level GVC Entry . . . . . . . . . . . . . . . . . 35

7.1.4 Determinants of Sector GVC Participation . . . . . . . . . . . . . . . 36

7.2 Economic Upgrading of GVC Links . . . . . . . . . . . . . . . . . . . . 36

7.2.1 Growth of GVC Links and Domestic Value Added in Exports . . . . . . . . . . . . . 36

7.2.2 GVC Links and Domestic Value Added . . . . . . . . . . . . . . . . . 37

7.2.3 GVC Participation and Firm-Level Productivity . . . . . . . . . . . . . 37

7.3 Social Upgrading of GVC Links . . . . . . . . . . . . . . . . . . . . . . 37

7.3 .1 Indirect Measures of Social Upgrading . . . . . . . . . . . . . . . . . . . 37

7.3.2 Direct Measures of Social Upgrading . . . . . . . . . . . . . . . 38

8 Policy Implications of GVCs $\quad 40$ 


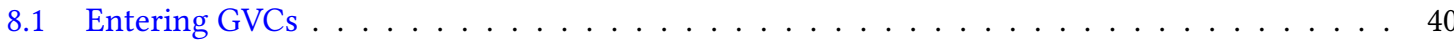

8.2 Expanding and strengthening GVC participation . . . . . . . . . . . . . . . . . 41

8.3 Turning GVC participation into sustainable development . . . . . . . . . . . . . . . 41

V Research Summary $\quad 42$

9 Statistical Analysis $\quad 43$

10 Tentative Chapters $\quad 45$ 


\section{Part I}

\section{Research Background}




\section{Chapter 1}

\section{Motivation}

A couple of major developments in the global economy, such as the revolution in ICT, deepening of trade liberalisation (and continuing transportation cost reduction) as well as some recent political developments are expanding the reach of globalisation through a gradual fragmentation of production processes across countries. Nowadays most of the products are composed of different designs and components produced by many suppliers (firms) with their operations in various countries, creating the global production networks. In fact, the typical "Made in" labels on manufactured goods have become old symbols of the past era. These days, more and more products are "Made in the World" rather than "Made in the USA" or "Made in China" (Antràs 2016).

Indeed, the global production (as a system of creating values in geographically separated tasks or phases) is eventually forming a world wide web of economic values or value added that explains the transitional structure of international trade and development. It is truly a new wave of globalisation, and it is termed as the global value chains (GVCs), creating the nexus among firms, workers and consumers around the globe. In general, from a industrial organisation perspective, value chains describe the sequence of productive (value-added) activities that capital and labour (or firms and workers) perform to bring a good or service from its conception to end use and beyond (Porter 1985, Sturgeon 2001). "Value chain analysis" is intended as the science of identifying bottlenecks and opportunities between different stages of production and tasks. It includes activities such as designing, administrative services, manufacturing, assembling, marketing, distribution and customer services. In the context of globalisation, these tasks that constitute a value chain have been carried out in inter-firm and intra-firm networks on a global scale (Gereffi et al. 2001, 2005). These value chains can be regional if the scope of production takes place within the same geographic region. From an economic perspective, the phenomenon of global value chains (GVCs) identifies a production structure in which tasks and business functions are distributed among several companies, globally, or regionally (Grossman \& Rossi-Hansberg 2012). The key features of GVCs are therefore the international dimension of the production process and the "contractualisation" of buyer and seller relationships, often across international borders (Antràs 2016). As a result, these international production networks are highly 
complex regarding geography, technology, and the variety of types of firms involved (from large retailers and highly large-scale mechanised manufacturers to small home-based production). Sometimes it may be impossible even to identify all the countries that are involved or the extent of their involvement (Gereffi \& Fernandez-Stark 2016). However, increasing international disintegration of production processes has been large enough to be salient in aggregate statistics.

GVC is truly a breakdown in the vertically-integrated mode of production-the so-called "Fordist" production. A variety of terms have been used to refer to this phenomenon: the "slicing of the value chain", "fragmentation of the production process", "disintegration of production", "delocalization", "vertical specialization", "global production sharing", "unbundling", "offshoring", "outsourcing" and many more (Antràs 2016, Feenstra 1998). We may use these terms interchangeably. Grossman \& Rossi-Hansberg (2012) rightly point out that the different tasks, rather than sectors, define the specialisation of countries in the value chains. The emergence of this new scenario is asking how an economy's production processes, producers and employees are connecting to the world trade and capturing the gains out of it regarding different dimensions of economic development.

We can use the GVC as the organising principle for the analysis of India's globalisation because it permits us to focus on India's global business strategy - including mass customisation, core competence, branding, and other barriers to entry, financialisation, and inducing competition among suppliers - that are crucial for corporate profitability. In fact, the value chain approach is particularly relevant for developing countries (especially for its firms) that seek to capture dynamic gains from world trade that come with economic and social upgrading within and across value chains (Milberg \& Winkler 2013).

Engagement in GVCs would not bring economic prosperity automatically. It requires much more value added from India's potential productive factors and upgrading quality \& quantity of those factors with a strong distributional aspect of socioeconomic opportunities and outcomes. In this situation, Milberg \& Winkler (2013) rightly suggest that to understand the welfare implications of India's global production networks, we need a shift in emphasis from static efficiency gains (resulting from specialisation and exchange) to the questions of the sources and uses of profits for firm investment, employment demand, and innovation. However, this analysis - undoubtedly focused on the production side - indicates that a heightened disembodying of the market forces will not promote a socially sustainable growth path for India. Therefore, we have to think about the policy options to maximise the dynamic gains from GVC engagement. Besides this, Gereffi \& Fernandez-Stark (2016) think about various tasks, i.e. decision about different types of industrial or economic upgrading (process, product, functional, or inter-sector), densification, social upgrading (employment, wages, or labour standards) and types of GVC governance (power relations) that India wants to pursue. Hence, Taglioni \& Winkler (2016) clearly point out three distinct focus areas with corresponding objectives and challenges. Firstly, entering GVCs - attracting foreign investors and facilitating domestic firms' entry into GVCs. Secondly, expanding and strengthening GVC participation - promoting economic upgrading and densification, and strengthening domestic firms' absorptive capacity. Thirdly, turning GVC participation into sustainable development - ensuring skill upgrading, social upgrading, and equitable dis- 
tribution of opportunities and outcomes while promoting environmental sustainability. In this context, evaluation of risks due to external shocks for surviving in the value chains is also relevant to consider. 


\section{Chapter 2}

\section{Geographical Background}

\subsection{Global Background}

Global value chains (GVCs) can simply be thought of as world wide web of economic value. From a business organization perspective, value chains describe the sequence of productive (value-added) activities that capital and labor (or firms and workers) perform to bring a good or service from its conception to end use and beyond (Porter 1985, Sturgeon 2001). "Value chain analysis" is intended as the science of identifying bottlenecks and opportunities between different stages of production and tasks. Value chains are said to be "global" when they include steps, processes, and actors from at least two countries (Gereffi et al. 2001, 2005); they can be regional if the scope of production takes place within the same geographic region. From an economic perspective, the phenomenon of global value chains (GVCs) identifies a production structure in which tasks and business functions are distributed among several companies, globally, or regionally (Grossman \& Rossi-Hansberg 2012). The key features of GVCs are therefore the international dimension of the production process and the "contractualisation" of buyer and seller relationships, often across international borders.

Producing high-quality goods and services in GVCs involves more than simply trading goods and services internationally. GVCs, in effect, integrate the know-how of lead firms and suppliers of key components along all the stages of production and in multiple companies and offshore locations. Typically coordinated by lead firms, GVCs involve international trade flows within their networks of foreign affiliates (foreign direct investment), contractual partners (non-equity modes of investment), and arm's-length external suppliers (UNCTAD 2013). When Toyota makes car parts in Thailand, it does not rely on local know-how. Instead, it imports Toyota technology, management, logistics, and any other bits of know-how not available in Thailand, because Thai-made parts have to fit seamlessly with parts made in Japan and elsewhere. GVCs, in effect, "unbundle" factories by offshoring firm-specific know-how along the stages of production, and those international flows of know-how are a key reason why GVCs offer unprecedented development 
opportunities to participating countries (Taglioni \& Winkler 2016).

Actually, well-functioning supply chains-which define the physical movement of goods all along the value chain, including domestic and international segments - are a key concern in GVCs. This is the case because good logistics, which defines the art of managing the supply chain and includes good connectivity, streamlined procedures for imports and exports, and low cost of logistics services, is an important determinant of countries' ability to join and strengthen participation in GVCs and a key factor in determining the costs of sourcing from and supplying to global markets. Getting to the border is one of the most pervasive constraints for exports of firms in low- and middle-income countries (LMICs), while the costs of logistics services can be disproportionately high for smaller and younger firms or for more remote locations. Improving logistics is also where LMICs have the most potential to reduce trade costs, according to recent surveys. Finally, well-functioning trade facilitation measures enable GVC trade by reducing the time, cost, and uncertainty involved in importing and exporting (Taglioni \& Winkler 2016).

But most production processes do not happen in a sequence of dependent activities. Instead, they take place in more complex networks of production, in which participating firms are specialists in one activity and external international sourcing arrangements imbue inter-firm trade with characteristics similar to intragroup trade: better control from the center, higher levels of bilateral information flow, tolerance of asset specificity, and harmonization and immediate integration of business processes that increase the potential for foreign activities to integrate seamlessly with activities performed at home. Large brand-carrying multinational enterprises (MNEs), such as IBM, Siemens, and Toyota, nowadays rely on a complex web of suppliers, vendors, and service providers of all kinds and in multiple locations. At the same time, a set of highly influential global buyers gained scale and influence in the 1990s, including retailers such as Walmart and Tesco and branded merchandisers such as Nike, Zara, and Uniqlo (Feenstra \& Hamilton 2006). Building on successful experiments in the 1970s and 1980s by a handful of pioneering retailers, such as J. C. Penney and Sears, global buyers nowadays place huge orders with suppliers around the world without establishing any factories or farms of their own (Gereffi 1999, Ponte \& Gibbon 2005). Unlike traditional MNEs, where equity ties link headquarters with foreign affiliates, global buyers link to their suppliers through non-equity external sourcing ties. Often, intermediaries (for example, trading companies such as Hong Kong SAR, China's Li \& Fung) are used to link buyers to producers in multiple countries (Taglioni \& Winkler 2016).

To highlight the complexity of the interactions among global producers, recent literature makes reference to the concept of global production "networks" rather than "chains" (Henderson et al. 2002). Accordingly, in the more realistic metaphor of networks, links can be seen as connecting nodes, some more central and some more peripheral. However, in this massive production network capital and labor are not the only factors of production. "Ideas" can be singled out as a third factor of production, although they could also be understood as high-skilled labor input. In a global context, the value-added activity performed in one country crosses international borders in goods or services tasks. Different tasks of the value chain contain a different amount of such factors of production. For example, specialized workers tend to be necessary in higher value-added tasks of the GVC. In the automotive, electronics, and electrical appliance industries, 
ideas are more strongly embedded in the early pre-production stages, such as research and development and design, or in post-production (logistics, marketing, and branding), thus requiring such specialized workers in those tasks. In other industries, notably the craft based ones (such as furniture making), innovation development is maximized when ideas (product design) and manufacturing operations are joint (Buciuni et al. 2013, Pisano \& Shih 2009), because innovation in those sectors often stems from a bottom-up approach (Breznitz \& Murphree 2011).

Hence, by focusing on the sequences of tangible and intangible value-adding activities, from conception and production to end use, GVC analysis provides a holistic view of global industries - both from the top down (for example, examining how lead firms "govern" their global-scale affiliate and supplier networks) and from the bottom up (for example, asking how these business decisions affect the trajectory of economic and social "upgrading" or "downgrading" in specific countries and regions).

\subsection{Indian Background}

India has emerged as one of the fastest growing economies in the world through different levels of liberalisation. Yet this growth has brought mixed economic and social outcomes. On one hand, recent studies of IMF and OECD show rising total factor productivity in Indian industry and exports have become more skill and capital intensive, suggesting that some Indian products are moving into tiers of value chains and that companies are generating demand for more skilled workers. On the other hand, different authors draw attention to problems of unbalanced growth between regions, the persistence of low quality informal work and adverse impact of trade liberalisation on more employment-intensive sectors and agriculture (Mazumdar \& Sarkar 2008, Pal et al. 2007). Given the rising prominence of India within the global economy and the need to create economic as well as social upgrading for its diverse forces of production, I should know more about India's increasing engagement in GVCs and its potential to contribute toward more inclusive economic and social development.

My purpose of this study is to present some relevant issues about India's GVC, such as degree of India's GVC linkages, by sector, by industry (including preliminary analysis by GVC measures as well as in-depth econometric analysis), consequences of GVCs for economic prosperity i.e. industrial or economic upgrading (including trade oriented upgrading and adaptation), impact of GVCs on social upgrading, such as reflection on labour market dynamics (because social upgrading is not immediately associated with industrial or economics upgrading). Some studies show that the impact of participation in GVCs has been mixed. Upgrading opportunities do exist within GVCs, but those studies show that these opportunities tend to be concentrated among certain regions, sectors, firms and workers rather than widespread. Furthermore, gains for MNCs do not automatically translate into gains for workers (Posthuma \& Nathan 2010).

Participation in certain types of value chains has been found to provide latecomer firms with a fast track to process and product upgrading (Schmitz 2004). This effect was confirmed among some domestic firms 
supplying to GVCs which improved their manufacturing process, enhanced product quality and sophistication, and raised productivity. Such firms have attained conformity with international technical and quality standards and increased their demand for skilled formal sector workers. These upgraded firms were mainly medium and large companies which had existing existing productive capacities and product development expertise prior to engagement with GVCs, or were companies which operate in higher technology and knowledge-intensive sectors such as information technology (IT). Positive spillovers were captured by smaller firms with adequate cash flow to invest in improved production practices and product quality, which also increased their requirements for skilled labour. As a result, workers with technical and managerial skills, many semi-skilled workers, and those having opportunities to learn on-the-job also benefited (Posthuma \& Nathan 2010).

Besides this, various exclusionary pressure also exist. Ponte (2008) draws attention to an adverse incorporation of smaller firms and lower-skilled workers which has led to the embedding of informal and precarious work within GVCs. Firms in less technologically sophisticated sectors with limited productive capacities faced upgrading barriers as well. There are also costs involved in upgrading, such as investments to attain quality. and product standards in the agri-food sector (Memedović \& Shepherd 2008). In some forms of value chain governance, lead firms may prevent upgrading of suppliers, leading to 'lock-in' at low valueadded, low-wage tiers (Schmitz 2006, Gibbon \& Ponte 2005). In fact, the cost-cutting nature of much GVCs and fluctuations in order schedules put pressures upon suppliers to compete by keeping costs low, which includes low-wage, flexible labour practices. While first-tier suppliers may gain under such circumstances, they survive by shifting price pressures and risks to smaller firms down their value chain. These practices are largely seen in the labour-intensive sectors such as garments, agriculture, and leather products as well as medium-technology sectors such as auto components. These negative externalities restrict profitability and inhibit the scope of for smaller firms to invest in equipment, new practices, and quality certification. While many jobs have been created, different studies provide evidence of the use of informal work throughout the tiers of many sectoral value chains, even among firms in the formal sector. Employment opportunities for women workers have been created in high tech sectors for more highly educated women, but the majority of these jobs are in labour-intensive, low-wage sectors (Posthuma \& Nathan 2010). 


\section{Part II}

\section{Research Significance}




\section{Chapter 3}

\section{Review of the Literature}

\subsection{Broad Perspective}

Internationally fragmented production is not new. For decades, low- and middle-income countries (LMICs) have imported parts from countries with more advanced technology, although generally only for the assembly of locally sold goods. Because the goods produced were not part of a global network, flows of know-how were less intense. The new characteristic of GVCs from a development perspective is that factories in LMICs have become full-fledged participants in international production networks. They are no longer just importing parts for assembly for local sales. They are exporting goods, parts, components, and services customized to the needs of the intended buyers and used in some of the most sophisticated products on the planet (Taglioni \& Winkler 2016).

Given the need for customization and integration of production facilities internationally, large multi national corporations (MNCs) seek to improve local innovation, knowledge-based capital, and competencies. The Samsung Group-which employs 369,000 people in 510 offices worldwide-worries about shortages of technical and engineering skills in Africa and how those shortages affect its efforts to embed its African workforce in Samsung's global production networks. In 2011, to address such shortages, Samsung launched Samsung Electronics Engineering Academies in Kenya, Nigeria, and South Africa. Outstanding performers are sent to annual Learner ship Programs in Seoul as part of Samsung's program for young leaders. The initiative serves the company's broader goal to develop 10,000 electronics engineers across the continent by 2015 (ACET 2014). Other corporations are investing in building the skill base in LMICs, too (Dunbar et al. 2013). Lucent Technologies supports education and learning programs in 16 countries throughout Africa, Asia, Europe, and Latin America; Nike and the United Kingdom's Department for International Development run a program to support access to economic assets for adolescent girls; Microsoft provides support to incorporate information technology (IT) into the daily lives of young people in the Philippines, Poland, the Russian Federation, and South Africa; Cisco provides funds, expertise, and equipment to create national 
networks of IT training centers in India, Mexico, South Africa, and the West Bank and Gaza, in addition to the work of the Cisco Networking Academy, which has 10,000 academies in 165 countries; finally, Nokia enhances life skills and leadership skills of young people in several countries, including Brazil, China, and Mexico (Taglioni \& Winkler 2016).

The new GVC-enabled flow of know-how from high-income countries to LMICs is a key factor in determining the role of GVCs in industrial development. LMICs can now industrialize by joining GVCs without the need to build their own value chain from scratch, as Japan and the Republic of Korea had to do in the twentieth century (Baldwin et al. 2012). That enables LMICs to focus on specific tasks in the value chain rather than producing the entire product, thereby lowering the threshold and costs for industrial development. LMICs can benefit from foreign-originated intellectual property; trademarks; operational, managerial, and business practices; marketing expertise; and organizational models. Countries have to understand the opportunities that GVCs offer and adopt the appropriate policies to mitigate the risks associated with them have the opportunity-through GVCs-to boost employment and productivity in all their agriculture, manufacturing, and services production. Job creation and labor productivity growth are sometimes viewed as competing goals, as higher labor productivity enables firms to produce a larger amount of value added without necessarily increasing the number of workers at the same rate (static productivity effects). Research shows that GVC integration leads to higher net jobs but lower job intensity (Calì et al. 2016, 2015) and has strong potential for productivity gains via several transmission channels (dynamic productivity effects), as discussed later, which go in hand with increased labor demand caused by more vertical specialization and higher output in GVCs.

\subsection{Firm Perspective}

The international location of new production facilities is ultimately in the hands of GVC lead firms. Conceptually, the new possibilities created by globalization and the information and communications technology revolution create two distinct sets of necessities for firms, which countries must address: (1) connecting factories and (2) protecting assets. Because cross-border factories must work as a unit, lead firms in GVCs care about efficiently connecting local factories with the relevant international production network and protecting proprietary assets. The predictability, reliability, and time sensitivity of trade flows are important factors behind firms' decision about a location, according to major trade and competitiveness indexes and case studies (WEF 2013). In many cases, countries cannot participate in certain parts of GVCs because of requirements for timely production and delivery. In effect, time is money in GVCs. A day of delay in exporting has a tariff equivalent of 1 percent or more for time-sensitive products (Hummels et al. 2007). Slow, unpredictable land transport keeps most of Sub-Saharan Africa out of the electronics value chain (Christ \& Ferrantino 2011). Lead firms and intermediate producers in GVCs need reliable, predictable, and timely access to inputs and final products to satisfy demand on time. Hence, good infrastructure and efficient borders are critical, as they relate to the predictability, reliability, and time sensitivity of trade flows. 
Strong, well-enforced property rights are the other element essential to attracting and keeping foreign investors (Feenstra et al. 2013). Firms export valuable, firmspecific technology and know-how, only part of which can be protected through patents, trademarks, and other forms of intellectual property regulations (IPRs). The know-how embodied in business and organizational models, operational and managerial practices, production processes, and export processes cannot be patented or trademarked; and even when intellectual property can be patented or trademarked, IPR treaties and domestic regulations aimed at promoting fair competition only imperfectly protect such know-how. Because GVCs necessarily involve contracting relationships between agents located in countries with heterogeneous legal systems and contracting institutions, "contracts are often neither explicit nor implicit; they simply remain incomplete" (Rodrik 2000). The way in which different national systems deal with contractual frictions and incomplete contracts and the way host countries enforce contracts between private parties are additional elements driving firms' choice of location, and those elements also factor into firms' boundaries in global sourcing (Antràs \& Chor 2013, Antràs \& Yeaple 2015). The connectivity of factories and the nature of contracting across countries are therefore key determinants-along with capital intensity-of a firm's decision to make or buy and whether to do so domestically or internationally.

Control of the subsidiary takes place in a variety of ways. The most strategic assets are tied to the lead firm through forms of direct capital control over the supplier (such as majority equity stakes). Assets of lower importance (such as older technologies) are instead just handed over through licensing agreements or other non-equity investments. Technical cooperation and arm's-length trade signal looser forms of collaboration. With the dramatic growth of outsourcing practices, competition between companies has shifted from horizontal (with firms competing in the same sector for the same customer base) to vertical (with firms in the same value chain competing to perform specific and specialized tasks). Lead firms compete with first-tier and lower-tier suppliers (Milberg 2004, Cattaneo et al. 2013, Cattaneo \& Miroudot 2013).

\subsection{Policy Perspective}

In the same way that import substitution industrialization gave way to export-oriented industrialization, the latter is now being replaced by efforts to identify an entry point into vertically specialized industries and upgrade within GVCs. Attracting offshore factories and ensuring domestic firm participation in international GVCs has become a major priority for many policy makers in LMICs. From a policy perspective, however, the critical issue is how GVCs integrate into the economy as a whole. Attracting and keeping offshore factories is not enough. Opening borders and attracting investment are important and help jump-start entry in GVCs. But to retain GVCs, maximize their benefit to the domestic economy, and ensure their sustainability, countries must integrate the domestic productive sector. The policy challenge extends, therefore, to creating and strengthening links with domestic firms and ensuring that the host country benefits from technology transfers, knowledge spillovers, and increased value addition in the country. If GVCs remain de-linked from the local context, lead firms drive many decisions, and governments may have limited influence and ability 
to leverage such decisions for domestic economic development. It is equally important to ensure that GVC participation benefits domestic society through more and better-paid jobs, better living conditions, and social cohesion. The right strategies can help LMICs increase and strengthen their participation in GVCs and foster development. Therefore, one of my aims (in this proposal) will be to discuss those right strategies with their enforcement and implications (quantitative as well as qualitative).

Nevertheless, a point to remember is that to create an effective and sustainable strategy of GVC participation, governments must focus on identifying key binding constraints and designing the necessary policy and regulatory interventions-as well as infrastructure and capacity building-with a "whole of value chain approach". Such an approach is needed to achieve development objectives through GVC participation and address specific challenges in entering GVCs, expanding and strengthening participation, and ensuring sustainability and inclusive growth. Trade and investment policies need to be connected with a wide-ranging domestic reform agenda aimed at helping countries enhance firms' productivity by building internal capacities and providing access to capital and connectivity, and ensuring a responsive and effective governance structure for identifying opportunities and addressing challenges from GVC participation.

According to Taglioni \& Winkler (2016), GVCs require targeted policies and analysis across a wide range of areas, which may not always be easy for a country's policy makers to formulate and connect to each other and to GVCs. Governments may not necessarily be aware of the effects of domestic policies on integration and upgrading in GVCs. The odds of success in GVCs are affected by policy and its implementation in areas as different as trade (tariff and nontariff barriers), domestic services regulations, investment regulations and incentives, compliance with process and product standards, innovation, industry, entrepreneurship, labor markets, education, and infrastructure and connectivity. Countries may not appreciate fully the importance of the synergies between the core areas of trade and investment regulation and well-tailored complementary measures. Countries also may not be able to identify the appropriate investment in education and vocational training, infrastructure, and connectivity; the best setting for labor market policies; which international standards to adopt; how to design and develop adequate supplier programs; effective cluster development programs and competitive spaces (special economic zones, growth poles, growth corridors, and so forth); or services regulations conducive to business efficiency. Finally, countries may not be able to identify and implement sustainable and effective financing and incentive schemes.

Even when governments are aware of these issues, putting in place regulations that do not unnecessarily restrict effectiveness in GVC participation may be difficult. In most countries, many agencies have a role in setting and enforcing regulation that may affect value chains and the efficiency of their supply chain. Those agencies also often legislate and implement regulation in an uncoordinated manner because regulators set policies with domestic regulatory objectives in mind. As a consequence, international coordination is not necessarily able to foster GVCs' production and trade along the corresponding supply chain. International coordination conflicts with domestic regulatory objectives may explain why existing trade agreements, investment agreements, and similar forms of international cooperation are rarely designed to foster GVC participation (Hoekman 2014). 
Given this background, OECD, WTO, World Bank, and different international as well as regional institutions are constantly suggesting that the policy maker's priority should be to identify and lift binding constraints, unlock productivity growth, and improve the overall competitiveness of the country. Many governments are willing to invest significant time and effort to adopt policy that influences the cost of production and trade within a GVC. The appropriate analysis and policy strategies can help trigger a virtuous cycle of "reform-GVC entry and upgrading-development", whereby the private sector is encouraged to keep investing retained earnings in the continued improvement of existing activities, new activities, and comparative advantage tasks in countries' agriculture, manufacturing, and services sectors, thereby generating a process of inclusive growth for the host country.

\subsection{Innovation Perspective}

Pietrobelli \& Rabellotti (2011) shows that Innovation, as a chain of processes, interact with GVC in multiple ways, and influence whether and how developing country firms learn and innovate through entering and interacting in these value chains. In general, LDC firms learn and innovate based on their participation in the GVC because they have to satisfy the product quality, delivery time, process efficiency, environmental, labor and social standards requirements of these chains. The learning mechanisms within GVC vary according to the form of governance that is adopted: they can be the result of pressure to match international standards or may be facilitated by direct involvement of the value chain leaders if the competence of suppliers is low and the risk noncompliance is high. When the actors in the value chain have complementary competences, learning is mutual and based on intense face-to-face interactions. In fact, it is from the 1980s on, with the debates surrounding the interpretation of the innovation process, that the perspective of innovation as a systemic and interactive process appears in the academic literature and in OECD policy documents, highlighting the importance of firms' both formal and informal networks, and giving rise to the concept of the innovation system (Szapiro 2016).

According to Lundvall et al. (2015), the notion of Innovation Systems, initiated by Economists bringing in the social dimension, is predominantly national level with advice on the design of national institutions and state policies for interactive learning between equal partners. Whereas the GVC approach, initiated by Sociologists bringing in economic perspectives, is developed to overcome limitations of nation state perspectives, where "governance" as the power dimension between the lead firm and the other firms in the value chain. Innovation System and Global value chain approach both see the promotion of development in less developed economies as the objective. Although these two approaches have common objective, but they are different mechanisms. Innovation system approach is about building absorptive capacity in less developed economies. Global value chain is about upgrading firms through linking up with foreign lead firms. Moreover, in terms of policy implications, the GVCs framework suggests that reducing trade barriers and policies aimed at attracting subsidiaries of multinational firms become a better alternative to industrial policies focused on substituting imports and increasing local content (Gereffi \& Sturgeon 2013). 
The literature on innovation systems, on the other hand, provides important elements for the understanding of the capability building process within firms, industries and sectors in developing countries (Szapiro 2016).

Actually, each approach has some obvious limitations. We know (from policy perspective) that to design intelligent institutions and policies at the national level requires an understanding of of the openness of the innovation system, which limits the scope of national system of innovation. Managing the openness including the dependence of foreign multinational firms is a major challenge for national governments. On the other hand, to understand how and to what degree a specific firm's or cluster's integration in a global value chain contributes to economic development requires an understanding of the national innovation system as context. However, there is a couple of earlier attempts to overcome these limitations. Pietrobelli \& Rabellotti (2011) started from Global Value Chain analysis and argue for including local, regional and national institutions' roles in upgrading opportunities. Ernst \& Kim (2002) started from Innovation System perspective and point to the need to take into account the role of global networks in relation innovation strategies. Malerba \& Nelson (2010) emphasised on catching-up and sectoral systems also combined the two perspectives. Indeed, the relationship between the GVC and IS is intrinsically dynamic, with frequent twoway directions of causality and continuous feedback. Governance patterns in GVC are dynamic and subject to continuous adjustments and changes. The characteristics of the innovation system affect this evolution. Therefore I should explore the co-evolving link between suppliers and the lead firms, and with them, of the related IS. 


\section{Chapter 4}

\section{Rationale and Scope of the Study}

This section brings my attention to the synergies between different areas of GVCs. I want to examine countries' (Obviously for India. If time permits, I would go for the comparative studies of India with a couple of other countries) efforts to identify the necessary reforms to trigger a virtuous cycle of "reformGVC-entry and upgrading-development". This cycle would encourage the private sector to keep investing retained earnings in the continued improvement of existing and new activities and tasks of comparative advantage in countries' agriculture, manufacturing, and services sectors.

The main motto of my research would be India's GVC engagement strategy. A two-step process (phase 1,2) can be envisaged for the overall country engagement strategy. In the first phase, I have to provide a comprehensive, fact-based, and independent preliminary view of India's trade competitiveness (particularly measured in value added), performance in GVC integration, economic upgrading, and the role of country characteristics, including the business climate, investment climate, and drivers of competitiveness across economic, regulatory, operational, and infrastructural dimensions. This (first phase) preliminary view could be developed through widest range of available and applicable methodologies followed by a (second phase) in-depth assessment and discussion of the identified challenges, opportunities, and policy options. This process allows for customizing the analysis to India-specific needs and overcoming the limits inherent in specific methodologies.

My research would includes (1) establishing the model of India's engagement and the appropriate institutional setting for identification of strategies in GVCs that offer the promise of the highest value added growth, as well as further investigation and/or validation of possible binding constraints and solutions, building on those identified in first phase of the India's engagement strategy and drilling down within GVCs; and (2) creating a detailed road map for understanding the reform process. For example, a possible strategy could be to identify a list of four to six major initiatives to maximize shared value added in incorporating global best practices and placing a priority on "quick wins".

The following scheme is the brief road map (combining phase 1 and 2) to assess India's participation in 
GVCs (i.e. identification of India's position in GVCs, its scope for economic as well as social upgrading, and some policy suggestions to achieve that goal) for my $\mathrm{PhD}$ proposal :

- Preliminary assessment of the India's growth in value added over time, sources of value added, location of final demand, and actors that drive the country's participation in GVCs.

- Identification and first-cut analysis of key sectors, GVCs, and firms that demand closer investigation.

- Identification of peer countries-for benchmarking purposes.

- Identification of challenges and needs at the micro (firm) and macro (country) levels to support entry and strengthening of GVC participation and long-term sustainability of the India's GVC strategy.

- Identification of policy areas for intervention and collection of evidence from international best practices

Planning of these two phases of my research should focus on the Indian economy as a whole, but also zoom into key industries, strategic segments therein, and individual value chains (as narrowly defined as the availability of quantitative and qualitative information allows). In other words, first phase provides a first-pass analysis of sector- and GVC-specific issues, which can be the object of more focused and deeper assessments in second phase of my research planning.

\subsection{Specific Aims}

In this scenario, I am very much interested in quantifying the extent and impacts of India's engagement in GVCs, based on available data. My research interest about India's GVCs comprises the following fundamental questions:

1. What are the determinants of India's global value chain (GVC) links (sector and industry-wise including preliminary analysis by GVC measures as well as in-depth econometric analysis)?

2. Do India's GVC links matter for industrial or economic upgrading (including learning, adaptation and trade oriented upgrading)?

3. Moreover, what is the relationship between India's GVC participation and social upgrading reflected on labour market dynamics (as social upgrading may not immediately associated with industrial or economic upgrading)?

Although the preliminary GVC participation measures defined in the previous subsection are partially suited to answer these questions, they can be used in combination with each other or with other measures to shed further light on two key questions policy makers need to ask: which policies help a country enter GVCs, and, more important, does GVC participation lead to development? 


\section{Part III}

\section{Research Design}




\section{Chapter 5}

\section{Analytical Framework of Assessing}

\section{India's Potential in GVCs}

Understanding the development process through competitive GVC participation needs a proper examination of the main factors behind the GVC integration and its measurements. Assessment of India's GVC participation requires three factors:

1. Functions in GVCs: considering India's performance as a buyer as well as seller in global market.

2. Specialisation and domestic value-added contribution: trends of specialisation in low or high value-added activities, and patterns of upgrading and development through GVCs.

3. Position in GVC network and type of GVC node: hub, incoming spoke, or outgoing spoke; clustering properties; and centrality in the global network

The multidimensionality of GVCs can be grasped by looking at the relationships between flows of goods, services and flows of factors of production (workers, ideas, and investments) - going beyond value added to look at the actors in GVCs and assess the effects of GVCs on jobs and wages (Taglioni \& Winkler 2016).

\subsection{Functions in GVCs: Buyer's and Seller's Perspectives}

Traditional trade theories assume that the whole production process of a product is taken place in one country and marketed in another. However, the notion of GVC trade is different - quantifying how much of India's export value is contributed by foreign countries. The basic concept is "importing to export," or I2E (Baldwin \& Lopez-Gonzalez 2015). For example, it indicates one country (India in my proposal) exports parts that are incorporated in the exports of another country (trading partner of India). That single flow of intermediate goods is the fundamental of two key measures of GVC participation: 
- On the sales side (seller's perspective), it indicates that Indian exporters are selling to a GVC.

- On the sourcing side (buyer's perspective), it indicates that a foreign country is buying from a GVC.

The term GVC trade typically refers to I2E manufactured goods and related services, but more generally it also includes imported raw materials used in exports. Importing to export on the sales and sourcing sides is linked to the bilateral concepts of backward and forward vertical specialisation (González \& Holmes 2011), in which "backward" refers to sourcing and "forward" to sales.

Actualisation of the I2E concept can be made through a distinction between the seller's and buyer's sides of GVC participation. In many cases, countries are GVC buyers and GVC sellers, but that distinction reflects the difference in economic mechanisms and determinants that lead to a country's successful performance in absorbing valuable foreign value added compared with growing domestic value embodied in GVC trade flows. Taglioni \& Winkler (2016) consider three types of buyer roles in GVCs: input purchases (1) for the production of final exports, (2) for the production of intermediate inputs in the value chain, and (3) for assembly. There are also three main seller functions: supply of (1) turnkey components, (2) primary inputs, and (3) other inputs.

The types of flows (goods, services, people, ideas, and capital) predominantly associated with the buyer's or seller's role are more easily discussed by first focusing on the buyer's or seller's functions separately and then considering them jointly. That evaluation is more easily actionable from the policy angle. If for example, the domestic value chain is found to be short, or little transformation is taking place domestically, the supplyside bottlenecks and opportunities for expansion on the buying side could be more readily identified than those on the selling side (Taglioni \& Winkler 2016).

\subsection{Specialisation and Value Addition}

It is evident that the most important things for the economics of GVCs are a generation of value addition and its growth over the time in India. Although value addition is a function of productivity, it is also associated with the breadth, variety, and sophistication of tasks and activities in which India specialises.

The range of activities in a value chain is very broad. The activities range from manufacturing inputs, outputs, and assembly operations to inbound and outbound logistics, marketing, sales, and a range of other service activities. Moreover, there are activities as diverse as the production of other inputs, machinery, and equipment, as well as R\&D, technological development, and functions aimed at organising the firm's infrastructure, human resource management, and procurement. Broadly, the value-added content of such activities and tasks tends to grow as the technological and know-how requirements needed to perform the task increase.

The value added in different industries can be in various segments of the value chain. The highest value added may lie with intangible activities, which are intensive in human capital and technology or tend to be 
located either at the beginning of the value chain (pre-production activities, such as basic and applied R\&D and design) or at the end (post-production activities driven by marketing knowledge, such as marketing, commercialisation, advertising, brand management, specialised logistics, and after-sale customer services) or the intangible, high value-added activities (such as design) are likely to take place jointly with production (Gereffi \& Frederick 2010, Buciuni et al. 2013).

Higher-income countries have a stronger specialisation in higher value-added activities within value chains. This fact reflects the greater use of technology and service inputs - whether in agriculture, manufacturing, or services, and whether in preproduction, production, or postproduction. Increased use of technology and service inputs is, in turn, the outcome of more complex knowledge- and capital-intensive activities. Besides this, the recent revolution of digitisation makes every step of the production process more productive and, in some cases, changes the nature of production (Taglioni \& Winkler 2016).

In a world dominated by complex and fragmented production processes, economic development can occur through industrial or economic upgrading and densification. Economic upgrading, often referred to as industrial upgrading or simply upgrading, is defined as the ability of producers to make better products, to make products more efficiently, or to move into more skilled activities (Pietrobelli \& Rabellotti 2006). Industrial or economic upgrading is largely about gaining competitiveness in higher value-added processes, products, tasks, and sectors in the form of process (improving process efficiency), product (introducing new products or improving existing products), functional (changing the mix of activities), and inter-sectoral upgrading (moving to a new value chain), embracing higher value-added production with the contribution of better skills and know-how, capital and technology, and processes (Cattaneo \& Miroudot 2013, Humphrey 2004, Humphrey \& Schmitz 2002, Kaplinsky \& Morris 2001). Densification involves engaging more local actors (firms and workers) in the GVC network, sensing the aspect of social upgrading. In some cases, this could mean that performing lower value-added activities on a larger scale can generate significant value addition for India. Raising domestic labour productivity and skills contributes to the overall goal to increase a country's (here India) value added as a result of GVC participation. This distributional aspect is essential to the analysis of the extent to which industrial or economic upgrading is associated with social upgrading (Milberg \& Winkler 2013). There are many variables adopted to measure economic and social upgrading at different levels of analysis: the nation, the sector or GVC, and the firm or the plant. Those are: 


\begin{tabular}{|c|c|c|}
\hline Level of aggregation & Economic Upgrading & Social Upgrading \\
\hline Country & $\begin{array}{c}\text { Productivity growth } \\
\text { Value added growth } \\
\text { Profits growth } \\
\text { Export growth } \\
\text { Growth in export market share } \\
\text { Unit value growth of output } \\
\text { Unit value growth of exports } \\
\text { Reduced relative unit labour costs }\end{array}$ & $\begin{array}{c}\text { Wage growth } \\
\text { Employment growth } \\
\text { Growth in labour share } \\
\text { Formal employment } \\
\text { Youth employment } \\
\text { Gender equality } \\
\text { Poverty reduction } \\
\text { Share of wage employment } \\
\text { Improved labour standards } \\
\text { Regulation of monitoring } \\
\text { Improved political rights } \\
\text { Human development index }\end{array}$ \\
\hline $\begin{array}{l}\text { Sector } \\
\text { or } \\
\text { GVC }\end{array}$ & $\begin{array}{c}\text { Productivity growth } \\
\text { Value added growth } \\
\text { Profits growth } \\
\text { Export growth } \\
\text { Growth in export market share } \\
\text { Unit value growth of output } \\
\text { Unit value growth of exports } \\
\text { Reduced relative unit labour costs } \\
\text { Increased capital intensity } \\
\text { Increased skill intensity of functions } \\
\text { Increased skill intensity of employment } \\
\text { Increased skill intensity of exports }\end{array}$ & $\begin{array}{l}\text { Wage growth } \\
\text { Employment growth } \\
\text { Labour standards }\end{array}$ \\
\hline Firm & $\begin{array}{l}\text { Skill intensity of functions } \\
\text { Skills to manage the supply chain } \\
\text { Composition of jobs } \\
\text { Capital intensity/mechanisation } \\
\text { Product, process, functional, chain }\end{array}$ & $\begin{array}{l}\text { Standards in plant monitoring } \\
\text { Number of workers per job }\end{array}$ \\
\hline
\end{tabular}

\subsection{Position in GVC Networks and Type of GVC Node}

In the context of complexity and multidimensionality of GVCs, network analysis can trace the overall performance of India's different actors and trade links. This assessment can be executed by creating a trade 
network topology, consisting of a set of centrality measures that capture various aspects of the network. The appropriate steps are:

- Strength: measuring average trade flow for India

- Closeness: capturing mean distance from India to all its trade partners

- Centrality: the location of India relative to the overall structure of the trade network through measures of "structural integration" in the network

- Clustering: the transitivity of the network - how much the neighbour countries of India are connected to each other in trade

- Visualisation through a minimal spanning tree: a process that illustrates the network reporting the strongest flow for each node

These can also illustrate other types of flows (for example, parts, components, services, or FDI) or flows in individual sectors or of specific products (Taglioni \& Winkler 2016).

\subsection{Policy Implications: Entering, Expanding, and Sustaining}

Engagement in GVCs would not bring economic prosperity in an automated manner. It requires much more value added from India's potential productive factors and upgrading quality \& quantity of those factors with a strong distributional aspect of socioeconomic opportunities and outcomes. These challenges truly create the scope for policy discussion. However, the policy options need a strategic framework to maximise the gains from GVC engagement. Taglioni \& Winkler (2016) points out three distinct focus areas with corresponding objectives and challenges. Those are:

1. Entering GVCs: attracting foreign investors and facilitating domestic firms' entry into GVCs.

- Creating World-Class GVC Links - improved connectivity to international markets

- Creating a World-Class Climate for Firms' Assets - assets protection and high-quality infrastructure and services

2. Expanding and strengthening GVC participation: promoting economic upgrading and densification, and strengthening domestic firms' absorptive capacity.

- Strengthening GVC-Local Economy Links - maximising the benefits from GVC spillovers

- Strengthening Absorptive Capacity - including innovation capacity, which, for example, could be measured by research and development intensity 
3. Turning GVC participation into sustainable development: ensuring skill upgrading, social upgrading, and equitable distribution of opportunities and outcomes while promoting environmental sustainability.

- Creating a World-Class Workforce - promoting skill development, social upgrading, and equitable distribution of opportunities and outcomes

- Implementing Climate-Smart Policies and Infrastructure

They also suggested thinking about various tasks i.e. decision about different types of industrial or economic upgrading (process, product, functional, or inter-sector), densification, social upgrading (employment, wages, or labour standards) and types of GVC governance (power relations) that an economy wants to pursue. In this context, evaluation of risks due to external shocks for surviving in the value chains is also relevant to consider. 


\section{Part IV}

\section{Research Methods}




\section{Chapter 6}

\section{Quantification of GVC Links}

I have already mentioned that my study would follow two phases of analysis i.e. the first phase/preliminary view would be developed through the widest range of available and applicable methodologies followed by a second phase/in-depth assessment and discussion of the identified challenges, opportunities, and policy options. The preliminary/first phase would use several statistical measures to examine the degree of India's GVC engagement. Those measures can be classified according to the levels of vertical integration, such as measures of backward integration, measures of forward integration, and some other statistical measures. I have summarised the main measures of forward and backward dimensions as well as the other crucial measures of India's GVC engagement in the following sections (data for all measures are easily available for India).

\subsection{GVC Participation Using Gross Trade Data}

Investigating India's potential in GVCs, at first, we have to use the gross trade flows. It requires to looking at the top export and import products, classified at the most disaggregated level. Execution of such initial insights increases the relevance of GVC analysis. In this first-cut analysis, we will handle three issues:

1. Compare product-level imports with export values, volumes, and prices of the top traded products (whether exports and imports follow different distributions and the values or volumes traded have distinct growth or level) to examine the degree of transformation within domestic segment of India's major GVCs (Taglioni \& Winkler 2016).

2. Use informed classifications (based on the WITS value chain category, OECD Bilateral Trade Database by industry and end-use category, and UN Classification of Broad Economic Categories) to extract as much information as possible from gross trade data (Sturgeon \& Memedović 2011, Athukorala 2011). Regrouping data in meaningful clusters or categorised by informed classifications focusing on 
consumer goods, capital goods, intermediates, and raw materials with sector analysis is beneficial (Taglioni \& Winkler 2016).

3. Document trade flows at the sub-national level to account India's degree of transformation within border when available.

These measures do not reveal whether the inputs are used domestically or exported. The following measures address this topic, focusing on imported inputs or foreign value added embodied in gross exports.

\subsection{Buyer's Perspective: Methods of Backward Links}

This section onward, different measures suggest ways identify the extent to which India and its peers source - domestically or internationally - the intermediates they use in exporting, which will provide the first indication of their participation in GVCs. The section then shows ways to quantify the domestic value added embodied in countries' exports (Baldwin \& Lopez-Gonzalez 2015). Key questions for sourcing dimension are: Where are India's exports made, and where is the value created?

\section{- Imported Inputs Embodied in Gross Exports:}

\section{I2E in Intermediate or Total Imports}

Measuring the India's intermediate imports embodied in its gross exports as a percentage of the India's total intermediate imports. Major businesses in GVCs perceive imports of goods and services as being important or critical for their exports (OECD-WTO 2013).

\section{I2E by Source Country}

A very useful indicator of GVC participation is the origin of the imported inputs embodied in India's gross exports.

\section{Distinguishing between Domestic and Foreign Value Added in Imports}

Imported inputs may contain domestic value added that is exported to a foreign location, processed, and re-imported. Re-importing and re-exporting can be quite important for some industries in India.

\section{- Value Added in Gross Exports:}

\section{Decomposition of Domestic Value Added}

The first-pass indicator simply distinguishes between domestic and foreign value added, usually expressed as a share of gross exports. The second pass digs deeper into where the domestic value added is actually created. This method breaks down the total domestic value added into three parts i.e. domestic value added in the particular sector - Direct domestic value added, domestic value added in upstream sectors supplying the sector with parts - Indirect domestic value added, 
and domestic value added in intermediates first shipped abroad for further processing and then re-imported - Re-imported intermediates

\section{Full Decomposition of Foreign Value Added}

The breakdown of foreign value added into source countries or industries is useful from a buyer's perspective because it identifies which foreign sources add the most value to its exports.

\section{- Length of Sourcing Chains:}

This measure that reflects such multi-country considerations captures by looking at a recursive measure of I2E on the sourcing side is the length of value chain sourcing (Fally 2011, De Backer \& Miroudot 2013). The TiVA data provide a handy means for comparing the average number of production stages in a given industry and country. An increase in GVC length over time suggests that the value chain has become more complex, with stages done in more countries.

Data Sources: Gross import data (UN Comtrade, BACI, WITS), categorized using informed classifications (BEC, parts and components, technical classifications); International I-O data (WIOD, TiVA, World Bank Export Value Added database); Enterprise surveys or other firm-level surveys.

\subsection{Seller's Perspective: Methods of Forward Links}

Key questions for the selling dimension are: Who are the ultimate customers for India's value added, and to what countries is India exporting its value added? India, for example, exports iron ore to China, but part of that product ends up in the United States and Germany rather than China. That is the seller's perspective.

\section{- Intermediates in Output or Gross Exports:}

A first basic measure of India's involvement in the production of inputs, as opposed to final goods, is the share of intermediates in gross output. The share of intermediates in gross exports takes the exporting perspective into account. The measure for India and Indian sectors, and relative to peers can provide a first-pass indication of whether India has become a more important supplier in GVCs.

\section{- I2E Trade in Gross Exports:}

The indicator importing to exports (I2E) in gross exports measures intermediates sold by a country to a buyer for use in the buyer's exports (I2E from the buyer's perspective) as a percentage of the seller's gross exports.

\section{- Domestic Value Added in Gross Exports of Third Countries:}

It indicates the contribution of domestically produced intermediates to exports in third countries. The only difference is that this indicator accounts only for the seller's intermediates that are domestically produced, whereas in the previous case the intermediates could also contain some foreign value added (Gaulier et al. 2013). 


\section{- Value Added in Final Domestic Demand:}

The Trade in Value Added (TiVA) and World Input-Output databases can also provide an understanding of the final consumers of India's value-added activities (OECD 2013).

\section{- Length of Selling Chains:}

GVC length on the sales side measure gauges the "upstreamness" of India's exports roughly, the number of downstream stages between India's producers and final consumers (Antràs et al. 2012, Chor 2014).

\section{- Domestic Gap between Buying and Selling Chains}

A final useful metric is to combine import and export upstreamness to compute the domestic gap between the buying and selling chains of individual sectors.

Data Sources: Production data (national statistics, UN-Stat manufacturing data set, firm-level data); Gross export data (Comtrade, BACI, WITS), categorized using informed classifications (broad economic category, parts and components, technical classifications); International I-O data (WIOD, TiVA, World Bank Export of Value Added database) and National I-O data; Enterprise surveys or other firm-level surveys.

\subsection{GVC Participation: Methods from Macro to Micro}

\section{- Additional useful measures of GVC participation:}

Beyond the Measures of Buying \& Selling Sides in India’s GVCs...

1. Illustrating how the buyer and seller dimensions can be combined to quantify an overall indicator i.e. the GVC participation index (Koopman et al. 2010).

2. Focusing on network metrics. It shows how a country's position overall, in a sector, in a specific GVC, and with respect to individual products can be measured and visualised using network metrics (Amador \& di Mauro 2015).

3. Paying special attention to the role of services in value added (Sáez et al. 2015, Francois et al. 2015).

4. Measures of direct links in GVCs using firm-level data - the micro perspective.

\section{- Links in GVCs Using Firm-Level Measures:}

1. Multinationals' Share of Inputs from Domestic Suppliers (Blalock \& Gertler 2008, Smarzynska Javorcik 2004, Havranek \& Irsova 2011)

2. Domestic Suppliers' Share of Output to Multinationals

3. Domestic Suppliers' Share of Exports 
4. Domestic Producers' Share of Imported Inputs

However, the second phase would follow various econometric tests with customised analysis to Indiaspecific needs and overcoming the limits inherent in the above methodologies. 


\section{Chapter 7}

\section{Drivers and Impacts of GVCs}

Actually, a fully developed regression model using firm- or sector-level data, for example, is preferable to bivariate correlations using country-level data, because the regression model allows the analysis to establish causality and dig into the drivers and impacts of GVC links at the micro level. That's why this subsection presents a research agenda and possible estimation strategies for ways to test for the drivers and impacts of India's GVC participation using statistical methods or econometrics or quantifying direct relationships in international input-output tables.

\subsection{Determinants of GVC Links}

This section focuses on different determinants of GVC links at the country, sector, and firm levels. The first step decomposes gross export growth into its components. If gross export growth is accepted as a measure of GVC links on the selling side, the decomposition allows for detecting how much of the value added is generated at home and abroad. The second part adopts two measures of GVC links - GVC integration at the country or sector level and a GVC participation dummy at the firm level.

\subsubsection{Decomposition of Gross Export Growth}

This measure would examine the level of significance of gross export growth onto its components i.e. direct domestic value added embodied in gross exports (intra-sector), indirect (upstream) domestic value added embodied in gross exports, re-imported domestic value added, and foreign value added embodied in gross exports. If gross export growth is accepted as a measure of GVC links on the selling side, the decomposition would allow for detecting how much of the value added is generated across countries (India and its peer countries) or sectors within India.

Now we should adopt two measures of India's GVC links - GVC integration at the country or sector level 
and a GVC participation dummy at the firm level. This research, indeed, focuses on different determinants of GVC links at the country, sector, and firm levels.

\subsubsection{Correlations of GVC Integration with Country-Level Characteristics}

Here we focus on the following three country characteristics, which, according to the economic literature, are important determinants of GVC participation: (1) logistics performance, (2) share of people with a tertiary education in the workforce, and (3) geographical distance to the closest global knowledge centers. However, initial insights can be gathered by assessing the statistical correlation between measures of GVC integration with those selected indicators at the country level. This analysis uses the measure of structural integration in GVCs (Amador \& di Mauro 2015).

\section{GVC Integration and Logistics Performance}

Good logistics performance is important because key components of GVC production are time sensitive, and reliable connectivity allows firms to connect factories across borders more efficiently. We will use the overall Logistics Performance Index (LPI) to quantify logistics performance. The LPI takes into account a country's customs efficiency, quality of trade and transport infrastructure, ease of arranging shipments, quality of logistics services, ability to track and trace consignments, and delivery times.

\section{GVC Integration and Skill Levels}

A skilled workforce is recognised as an important determinant of countries' success in GVCs because it allows producing at the high standards of productivity, efficiency, sophistication, and timeliness required to serve global markets. We will use the share of workers with tertiary education to quantify the skill level.

\section{GVC Links and Geographical Distance to Knowledge Centers}

Countries closer to the hubs in GVCs and to the global centers of knowledge are favoured by easier access to tacit knowledge. Unlike knowledge embodied in technology, tacit knowledge requires frequent and continued face-to-face interaction between the staff and managers of lead firms or turnkey suppliers and those of other firms in the GVC, and the importance of tacit knowledge increases for more complex tasks. We will use the geographical distance from Germany, Japan, and the United States as a proxy for distance from knowledge centers.

\subsubsection{Determinants of Firm-Level GVC Entry}

Following the literature on the firm-level determinants of exporting, the model includes firm size, firm age, foreign ownership status, as well as measures of workers' skills and productivity as determinants of GVC 
participation. Here we also try to amend the Roberts \& Tybout (1997) theoretical model on the determinants of exporting.

\subsubsection{Determinants of Sector GVC Participation}

If firm-level data - in particular, information on GVC participation - are not available, an alternative could be to estimate the impact of the policy determinants on sector GVC participation in India.

\subsection{Economic Upgrading of GVC Links}

This section focuses on the role of GVC links for economic upgrading. Three main measures of economic upgrading are adopted: (1) growth of domestic value added embodied in gross exports at the sector level in the first section, (2) level of domestic value added at the sector level in the second section, and (3) firm-level labor productivity in the third section. Different measures of GVC links are also explored, including GVC measures of structural integration as buyers and sellers in networks, foreign value added embodied in gross exports, domestic value added embodied in exports of third countries, GVC participation index, position in GVCs (upstreamness), domestic length of sourcing chains, and share of foreign output in a sector.

\subsubsection{Growth of GVC Links and Domestic Value Added in Exports}

Do the intensity and nature of GVC links matter for growth in domestic value added that is exported? This question can be explored through econometric analysis from several angles i.e. (a) whether the degree of structural integration in global value-added trade matters, (b) econometric analysis can be used to investigate how greater integration of India in GVCs as a buyer - as opposed to weaker integration as a seller (that is, more unbalanced GVC integration) - affects domestic value-added growth from gross exports, (c) the analysis can examine more closely the relation between the growth of foreign value added embodied in gross exports and the domestic value-added component, (d) it can look at the role of India's position in the value chain (upstreamness or distance to final demand), and (e) econometrics can be used to investigate the role of the domestic length of the sourcing chains.

1. Growth of GVC Participation and Domestic Value Added Embodied in Exports

2. Growth of Balanced GVC Participation and Domestic Value Added Embodied in Gross Exports

3. Growth of Foreign and Domestic Value Added Embodied in Gross Exports

4. Growth of Upstreamness and Domestic Value Added Embodied in Gross Exports 
5. Growth of Domestic Length of Sourcing Chains and Domestic Value Added Embodied in Gross Exports

\subsubsection{GVC Links and Domestic Value Added}

It focuses on the effect of GVC integration, as a buyer and a seller, on domestic value added, also taking into account the mediating role of national policy. Domestic value added is generated by combining labour with capital stock, and is dependent on a country's technology shifter. The technology shifter is assumed to be a function of international trade and innovation, which is consistent with the trade literature (Kummritz et al. 2017).

\subsubsection{GVC Participation and Firm-Level Productivity}

1. Within-Industry Impact of FDI:

The method focuses on the within industry impact of foreign output share on domestic firm productivity and the role of mediating factors. Specifically, Farole \& Winkler (2014b) ask, what is the potential of global production networks to enhance the productivity of domestic firms?

2. Within-Industry Impact of Structural Integration in GVCs:

Similarly, the analysis can be used to examine the effect of GVC participation of an industry on a firm's productivity by merging the Farole \& Winkler (2014b) data set with two sector measures of structural integration, computed by Amador \& di Mauro (2015), in India’s GVCs.

\subsection{Social Upgrading of GVC Links}

This section addresses which GVC-oriented industries have a higher demand for labour, such that integrating into GVCs in those sectors has a greater potential to create jobs and increase household income (Calì et al. 2016, Calì \& Hollweg 2017). We have following measures (using World Bank's LACEX database) that can be used to identify the impact on labour and wages. The measures are categorised in two groups: indirect measures of social upgrading, and direct measures of social upgrading (Taglioni \& Winkler 2016).

\subsubsection{Indirect Measures of Social Upgrading}

This subsection presents indirect measurements of the link between GVC participation and labour market outcomes. The specific sectors that are relevant for participation in GVCs can be analysed using the following methods. 


\section{Descriptive Statistics}

Descriptive statistics may be used to assess which sectors are associated with better labour market outcomes. I would examine India and its peer countries' sector averages of the number of employees, wages and salaries, wage rate (wages and salaries divided by the number of employees), or labour share (wages and salaries as a percentage of value added). Such statistics, for example, can be obtained from the United Nations Industrial Development Organisation's Industrial Statistics database.

\section{Analysis of Employment-Generating Industries and Their Level of GVC Integration}

This analysis may be carried out by running cross-country "controlled correlations" at the sector level, whereby the labour market indicators discussed in the previous section are regressed on indicators of GVC involvement while controlling for other factors, such as region and gross domestic product. The analyst can also run pooled regressions controlling for industry fixed effects to see which industries have more labour-market-enhancing outcomes conditional on GVC involvement.

\subsubsection{Direct Measures of Social Upgrading}

This subsection presents more direct measurements of the link between GVC participation and labour market outcomes by drawing on various indicators already developed in the literature (Taglioni \& Winkler 2016).

\section{Labor Content of Gross Exports}

This direct measure of social upgrading is the labour content of gross exports. The newly developed World Bank data set on LACEX can be used to explore the social upgrading linked to GVC participation (Calì et al. 2016). The data set is computed on the basis of the social accounting matrix data available in the Global Trade Analysis Project for intermittent years between 1995 and 2011.

\section{Labour Component of Domestic Value Added in Exports}

This direct measure of social upgrading, which was developed by the United Nations Conference on Trade and Development (UNCTAD 2013), is the labour cost component of domestic value added in exports, which acts as a proxy for the employment generating potential of exports.

\section{Jobs Sustained by Foreign Final Demand}

This indicator, jobs sustained by foreign final demand, is being developed by OECD-WTO as part of the TiVA database for 40 countries. The indicator calculates the number of jobs in the total economy sustained by foreign final demand, which captures the full upstream impact of final demand in foreign markets on domestic employment. Rather than consider the domestic value added in total exports (as was the basis of the previous indicator), which could be used as intermediates in third countries and be exported as final goods, the indicator considers the domestic value added in foreign final demand.

\section{Jobs Generated by Foreign Trade in GVCs}


India's participation in GVCs can lead to domestic or foreign labour demand. So this indicator is the number of jobs generated by India's trade in GVCs - jobs generated domestically and abroad - using the World Input-Output Database (WIOD). The sources of employment creation from international trade are labour demand from final goods trade and trade in intermediates, or the result of India's GVC participation (Jiang \& Milberg 2013).

\section{Jobs in GVC Manufacturing}

The jobs in the GVC manufacturing indicator will present a broader picture of the structure of employment in GVCs within India and its peers using WIOD. It is the most direct measure in the literature of the domestic employment impacts of manufacturing GVC participation The indicator would measure - directly and indirectly - the number of GVC jobs involved in the production of final manufacturing goods (also known as manufactures), as well as their sector of employment in India (Timmer et al. 2014).

However, the quality of the assessment depends on the methodology that is applied, which, in turn, depends heavily on data availability. 


\section{Chapter 8}

\section{Policy Implications of GVCs}

Engagement in GVCs would not bring economic prosperity in an automated manner. It requires much more value added from India's potential productive factors and upgrading quality \& quantity of those factors with a strong distributional aspect of socioeconomic opportunities and outcomes. These challenges truly create the scope for policy discussion. However, the policy options need a strategic framework to maximise the gains from GVC engagement. To develop an effective and sustainable strategy of GVC participation, we must identify key binding constraints and suggest the necessary policy and regulatory interventions as well as infrastructure and capacity building. That's why this part of my thesis points out three distinct focus areas with corresponding objectives and challenges (Taglioni \& Winkler 2016).

\subsection{Entering GVCs}

This first focus discusses ways for India and its peers to enter global production networks. Those avenues include ways to attract foreign investors, as well as strategies to enhance the participation of domestic firms in GVCs. Suggestions for entering GVCs encompass measures to ensure that India can offer world-class links to the global economy and create a friendly business climate for foreign tangible and intangible assets.

1. Creating World-Class GVC Links - jump-starting GVC entry through the creation of EPZs and other competitive spaces (Milberg \& Winkler 2013), attracting the "right" foreign investors as foreign investors vary in their potential to deliver spillovers (Farole \& Winkler 2014a), helping domestic firms find the "right" trade partners and technology abroad, improving connectivity to international markets (OECD-WTO 2013).

2. Creating a World-Class Climate for Firms' Assets - ensuring cost competitiveness while avoiding the trap of low-cost tasks, improving drivers of investment and protecting foreign assets, organising domestic value chains and improving the quality of infrastructure and services (Cattaneo et al. 2013). 


\subsection{Expanding and strengthening GVC participation}

This second focus discusses ways for India and its comparator countries to lever their position in GVCs to achieve higher value addition through economic upgrading and densification. The concept of economic upgrading is largely about gaining competitiveness in higher-value-added products, tasks, and sectors. Densification involves engaging more local actors (firms and workers) in the GVC network. Strengthening GVC-local economy links, absorptive capacity, and skills contributes to the overall goal to increase India's value added that results from GVC participation.

1. Strengthening GVC-Local Economy Links on the Buyer's and Seller's Sides (Farole \& Winkler 2014a).

2. Strengthening Absorptive Capacity - maximizing the absorption potential of local actors to benefit from GVC spillovers (Farole \& Winkler 2014a), Fostering Innovation and Building Capacity (Cattaneo et al. 2013).

3. Creating a world-class Workforce through skill development (Cattaneo et al. 2013).

\subsection{Turning GVC participation into sustainable development}

The third one focuses on social and environmental sustainability of India's GVCs. Labour market-enhancing outcomes for workers at home and more equitable distribution of opportunities and outcomes create social support for a reform agenda aimed at strengthening India's GVC participation. Climate-smart policy prescriptions and infrastructure can mitigate the challenges for firms from climatic disruptions, ensuring the long-term predictability, reliability, and time-sensitive delivery of goods necessary to participate in GVCs.

- Creating a World-Class Workforce - promoting skill development, social upgrading, and equitable distribution of opportunities and outcomes.

- Implementing Climate-Smart Policies and Infrastructure through proper environmental regulation and innovation in green technologies. 


\section{Part V}

\section{Research Summary}




\section{Chapter 9}

\section{Statistical Analysis}

Now I have to provide a summary of the probable methodologies available to carry out the GVCs' assessment and their content in my thesis.

- Macroeconomic trends: Value added by broad sector, employment by broad sector, labor productivity by sector, FDI, exports and imports (\% of GDP), exports and imports by broad economic category, and other informed classifications.

- Export market share growth, push, and pull factors: Export market share growth; decomposition in push and pull factors using shift-share methodologies.

- Measuring Competitiveness in GVCs: Trade in main GVCs, exports of GVC products relevant to India, top five exports, including country dimensions and follow-up analysis of interesting patterns (such as product-specific analysis).

- Network analysis: Worldwide trade network, country trade network for sector of interest (main buyers), country trade network for sector of interest (main suppliers), and Extension to more sectors (four or five, maximum).

- Trade in value-added indicators: Domestic value added in gross exports (total growth and by sector), decomposition, foreign value added in gross exports, domestic value added in third countries' exports, sourcing and selling patterns, value added by destination, import and export upstreamness and gap, contribution of direct and indirect domestic value added and foreign value added to gross export growth.

- Econometric assessment: Impact of structural integration in GVCs (network measure) on domestic value added embodied in exports and gross exports. Probabilistic model of entry in GVCs. Impact of GVC integration (foreign value added in gross exports, domestic value added in third countries' exports) on value added and the role of national policies. Impact of GVC integration (imported input share, export share, etc.) on labor productivity and the role of absorptive capacity. 
- Role of services in GVCs: Zoom into the services dimension of GVC analysis

- Product-specific case study: Value chain mapping and country positioning, historical/current trends, stakeholder/actor analysis, challenges and opportunities, future implications, policy implications.

- Policy section: policy suggestions based on GVC analysis, screening of policy performance indicators etc.

Indeed, I need a sound knowledge base in policy and strategic issues related to trade in general and GVCs in particular, as well as technical skills in analyzing trade and production data at the macro and firm levels. Ideally, I should have some knowledge in GVC analysis and, most important, in depth country knowledge. If I intend to do in-depth technical analysis as well, technical tools must be learned. If I consider certain methodologies essential from the outset, then bringing in specialized technical expertise to lead those components may be useful. 


\section{Chapter 10}

\section{Tentative Chapters}

Indeed, (on the basis of literature review) research is required to obtain a clearer \& an exclusive understanding of India's circumstances under which more inclusive and sustained economic as well as social upgrading in GVCs can be attained for all industry and workers. As part of this study, the chapters in this PhD dissertation would contribute some research findings that shed on several key questions that can be addressed with the tools described in the previous sections include the following:

\section{- Chapter 1: Multidimensional Assessment of India’s GVC Linkages}

- How extensive is India's GVC participation (by sector, by industry)? What is India's (by sector or product) degree of centrality and structural integration in GVCs?

- Which are the source countries of foreign value added that are used as an input in the India's exports?

- Which countries are the final consumers of domestic value added embodied in the India's exports?

- What is India's performance and what are its main functions in GVCs (buyer or seller; predominantly headquarters, factory, or assembly location)?

- Are Indian firms well integrated in GVCs?

- Through which channels and in which sectors do Indian value-added products and services contribute most to its gross exports?

- Chapter 2: Impact of GVCs on India's Economic and Social Prosperity

- Does the position (upstream/downstream) of India's (by sector or industry) participation in GVCs matter for domestic value added and growth of domestic value added?

- What is the impact of India's GVC participation on task trade (goods and services) and the factors of production (such as workers, ideas, and investments)? 
- Is GVC participation creating positive effects and spillovers to the Indian economy?

- Chapter 3: Policy Implications for Greater Prosperity

- Which form of GVC participation can India pursue?

- How can GVC tasks be identified?

- What are the possible risks of India's GVC participation?

- Which forms of governance exist between lead firms and suppliers?

- Which power relations characterize specific GVCs?

- What are the GVC transmission channels?

- Which type of economic and social upgrading can India pursue?

- Which foreign firm, Indian firm, and India's characteristics influence GVC spillovers?

- What is the relationship between economic and social upgrading in Indian economy, and is downgrading a possibility?

- What are the links between social upgrading and cohesion?

- What benefits to sustainable India's GVC participation can originate from environmental regulation? 


\section{Bibliography}

ACET (2014), African transformation report: Growth with depth, Technical report, African Center for Economic Transformation, Accra, Ghana: ACET.

Amador, J. \& di Mauro, F. (2015), 'The age of global value chains: maps and policy issues', VoxEU eBook, Centre for Economic Policy Research.

Antràs, P. \& Chor, D. (2013), 'Organizing the Global Value Chain’, Econometrica 81(6), 2127-2204.

Antràs, P., Chor, D., Fally, T. \& Hillberry, R. (2012), 'Measuring the upstreamness of production and trade flows', The American Economic Review 102(3), 412-416.

Antràs, P. \& Yeaple, S. R. (2015), 'Multinational Firms and the Structure of International Trade', Handbook of International Economics 4, 55-130.

Antràs, P. (2016), Global Production: Firms, Contracts, and Trade Structure, Princeton University Press.

Athukorala, P.-c. (2011), 'Production networks and trade patterns in east asia: Regionalization or globalization?', Asian Economic Papers 10(1), 65-95.

Baldwin, R. \& Lopez-Gonzalez, J. (2015), 'Supply-chain trade: A portrait of global patterns and several testable hypotheses', The World Economy 38(11), 1682-1721.

Baldwin, R., Venables, A. J. \& Bridgman, B. (2012), 'Global supply chains: Why they emerged, why they matter, and where they are going', Journal of International Economics 90(1), 245-254.

Blalock, G. \& Gertler, P. J. (2008), 'Welfare gains from foreign direct investment through technology transfer to local suppliers', fournal of International Economics 74(2), 402-421.

Breznitz, D. \& Murphree, M. (2011), Run of the red queen: Government, innovation, globalization, and economic growth in China, Yale University Press.

Buciuni, G., Coro', G. \& Micelli, S. (2013), 'Rethinking the role of manufacturing in global value chains. An international comparative study in the furniture industry', Industrial and Corporate Change pp. 1-30.

Calì, M., Francois, J., Hollweg, C. H., Manchin, M., Oberdabernig, D. A., Rojas-Romagosa, H., Rubinova, S. \& Tomberger, P. (2016), 'The labor content of exports database', World Bank Policy Research Working Paper 7615 . 
Calì, M. \& Hollweg, C. H. (2017), 'How much labor do south african exports contain?'.

Calì, M., Hollweg, C. et al. (2015), The labor content of exports in south africa and botswana, Technical report, The World Bank.

Cattaneo, O., Gereffi, G., Miroudot, S. \& Taglioni, D. (2013), 'Joining, upgrading and being competitive in global value chains: a strategic framework', World Bank Policy Research Working Paper 6406 pp. 1-50.

Cattaneo, O. \& Miroudot, S. (2013), 'From global value chains to global development chains: An analysis of recent changes in trade patterns and development paradigms', 21st Century Trade Policy: Back to the Past

Chor, D. (2014), 'Where are countries positioned along global production lines?', Macroeconomic Review pp. $94-99$.

Christ, N. \& Ferrantino, M. J. (2011), 'Land Transport for Export: The Effects of Cost, Time, and Uncertainty in Sub-Saharan Africa', World Development 39(10), 1749-1759.

De Backer, K. \& Miroudot, S. (2013), 'Mapping global value chains'.

Dunbar, M. et al. (2013), 'Engaging the private sector in skills development', Health \& Education Advice and Resource Team. Oxford Policy Management, Oxford, England .

Ernst, D. \& Kim, L. (2002), 'Global production networks, knowledge diffusion, and local capability formation', Research policy 31(8), 1417-1429.

Fally, T. (2011), 'On the fragmentation of production in the us', University of Colorado mimeo .

Farole, T. \& Winkler, D. (2014a), Making foreign direct investment work for Sub-Saharan Africa: Local spillovers and competitiveness in global value chains, World Bank Publications.

Farole, T. \& Winkler, D. (2014b), 'The role of mediating factors for fdi spillovers in developing countries: Evidence from a global dataset'.

Feenstra, R. C. (1998), 'Integration of trade and disintegration of production in the global economy', The journal of economic perspectives 12(4), 31-50.

Feenstra, R. C. \& Hamilton, G. G. (2006), Emergent economies, divergent paths: Economic organization and international trade in South Korea and Taiwan, Vol. 29, Cambridge University Press.

Feenstra, R. C., Hong, C., Ma, H. \& Spencer, B. J. (2013), 'Contractual versus non-contractual trade: The role of institutions in China', Journal of Economic Behavior and Organization 94, 281-294.

Francois, J., Manchin, M. \& Tomberger, P. (2015), 'Services linkages and the value added content of trade', The World Economy 38(11), 1631-1649.

Gaulier, G., Santoni, G., Taglioni, D. \& Zignago, S. (2013), 'In the wake of the global crisis: evidence from a new quarterly database of export competitiveness'. 
Gereffi, G. (1999), 'International trade and industrial upgrading in the apparel commodity chain', fournal of international economics 48(1), 37-70.

Gereffi, G. \& Fernandez-Stark, K. (2016), Global value chain analysis: a primer, Duke CGGC (Center on Globalization, Governance \& Competitiveness).

Gereffi, G. \& Frederick, S. (2010), 'The global apparel value chain, trade and the crisis: challenges and opportunities for developing countries', World Bank Policy Research Working Paper Series 5281.

Gereffi, G., Humphrey, J., Kaplinsky, R. \& Sturgeon*, T. J. (2001), 'Introduction: Globalisation, Value Chains and Development', IDS Bulletin 32(3), 1-8.

Gereffi, G., Humphrey, J. \& Sturgeon, T. (2005), 'The governance of global value chains', Review of International Political Economy 12(1), 78-104.

Gereffi, G. \& Sturgeon, T. (2013), 'Global value chain-oriented industrial policy: the role of emerging economies', Global value chains in a changing world p. 329.

Gibbon, P. \& Ponte, S. (2005), Trading down: Africa, value chains, and the global economy, Temple University Press.

González, J. L. \& Holmes, P. (2011), 'The nature and evolution of vertical specialisation: What is the role of preferential trade agreements?', NCCR Trade Working Paper 2011/41.

Grossman, G. M. \& Rossi-Hansberg, E. (2012), 'Task trade between similar countries', Econometrica 80(2), 593-629.

Havranek, T. \& Irsova, Z. (2011), 'Estimating vertical spillovers from fdi: Why results vary and what the true effect is', Journal of International Economics 85(2), 234-244.

Henderson, J., Dicken, P., Hess, M., Coe, N. \& Yeung, H. W.-C. (2002), 'Global production networks and the analysis of economic development', Review of International Political Economy 9(3), 436-464.

Hoekman, B. (2014), 'Supply chains, mega-regionals and multilateralism: a road map for the wto', Robert Schuman Centre for Advanced Studies Research Paper No. RSCAS 27.

Hummels, D., Minor, P., Reisman, M. \& Endean, E. (2007), 'Calculating tariff equivalents for time in trade', USAID Report, March .

Humphrey, J. (2004), 'Upgrading in global value chains'.

Humphrey, J. \& Schmitz, H. (2002), 'How does insertion in global value chains affect upgrading in industrial clusters?', Regional studies 36(9), 1017-1027.

Jiang, X. \& Milberg, W. (2013), 'Capturing the jobs from globalization: trade and employment in global value chains'.

Kaplinsky, R. \& Morris, M. (2001), A handbook for value chain research, Vol. 113, IDRC Ottawa. 
Koopman, R., Powers, W., Wang, Z. \& Wei, S.-J. (2010), Give credit where credit is due: Tracing value added in global production chains, Technical report, National Bureau of Economic Research.

Kummritz, V., Taglioni, D. \& Winkler, D. (2017), 'Economic upgrading through global value chain participation'.

Lundvall, B., Jurowetzki, R. \& Lema, R. (2015), 'Combining the global value chain and the innovation system perspectives', Aalb. Univ. Dep. Bus. Manag .

Malerba, F. \& Nelson, R. (2010), Catching up in different sectoral systems: evidence from six industries, in 'Globelics Conference, Kuala Lumpur, Malaysia', p. 2010.

Mazumdar, D. \& Sarkar, S. (2008), Globalization, labor markets and inequality in India, Vol. 79, Idrc.

Memedović, O. \& Shepherd, A. (2008), Agri-food Value Chains and Poverty Reduction: Overview of Main Issues, Trands and Experiences, United Nations Industrial Development Organization.

Milberg, W. (2004), 'The changing structure of trade linked to global production systems: What are the policy implications?', International Labour Review 143 (1-2),(1), 45-90.

Milberg, W. \& Winkler, D. (2013), Outsourcing economics: global value chains in capitalist development, Cambridge University Press.

OECD (2013), 'Science, technology and industry scoreboard 2013’.

OECD-WTO (2013), 'Aid for trade at a glance 2013'.

Pal, P., Ghosh, J. et al. (2007), 'Inequality in india: A survey of recent trends', Economic and Social Affairs Working Paper 45.

Pietrobelli, C. \& Rabellotti, R. (2006), 'Clusters and value chains in latin america: In search of an integrated approach', Upgrading to compete: global value chains, clusters, and smes in Latin America pp. 1-40.

Pietrobelli, C. \& Rabellotti, R. (2011), 'Global value chains meet innovation systems: are there learning opportunities for developing countries?', World Development 39(7), 1261-1269.

Pisano, G. P. \& Shih, W. C. (2009), 'Restoring american competitiveness'.

Ponte, S. (2008), 'Developing a vertical dimension to chronic poverty research: Some lessons from global value chain analysis', Chronic Poverty Research Centre Working paper .

Ponte, S. \& Gibbon, P. (2005), 'Quality standards, conventions and the governance of global value chains', Economy and Society 34(1), 1-31.

Porter, M. E. (1985), Competitive Advantage: Creating and sustaining superior performance, The Free Press.

Posthuma, A. \& Nathan, D. (2010), Labour in Global Production Networks in India, Oxford University Press.

Roberts, M. J. \& Tybout, J. R. (1997), 'The decision to export in colombia: an empirical model of entry with sunk costs', The American Economic Review pp. 545-564. 
Rodrik, D. (2000), 'How Far Will International Economic Integration Go?', fournal of Economic Perspectives 14(1), 177-186.

Sáez, S., Taglioni, D., Van der Marel, E., Hollweg, C. H. \& Zavacka, V. (2015), Valuing services in trade: a toolkit for competitiveness diagnostics, World Bank Publications.

Schmitz, H. (2004), Local upgrading in global value chains: recent findings, in 'International Convention Centre. Durban, South Africa', Vol. 21, pp. 1-8.

Schmitz, H. (2006), 'Learning and earning in global garment and footwear chains', The European fournal of development research 18(4), 546-571.

Smarzynska Javorcik, B. (2004), 'Does foreign direct investment increase the productivity of domestic firms? in search of spillovers through backward linkages', The American Economic Review 94(3), 605-627.

Sturgeon, T. J. (2001), How Do We Define Value Chains and Production Networks?, Technical Report 3, IDS Bulletin.

Sturgeon, T. J. \& Memedović, O. (2011), Mapping global value chains: Intermediate goods trade and structural change in the world economy, United Nations Industrial Development Organization.

Szapiro, M. (2016), Global Value Chains and National Systems of Innovation: policy implications for developing countries, PhD thesis, Universidade Federal do Rio de Janeiro.

Taglioni, D. \& Winkler, D. (2016), Making Global Value Chains Work for Development, Vol. Trade and Development series, Washington, DC: World Bank.

Timmer, M. P., Erumban, A. A., Los, B., Stehrer, R. \& de Vries, G. J. (2014), 'Slicing up global value chains', The fournal of Economic Perspectives 28(2), 99-118.

UNCTAD (2013), 'Global value chains and development', World Investment Report 2013.

WEF (2013), Enabling trade: Valuing growth opportunities, in ‘World Economic Forum’. 